\title{
Hydrogeochemical characteristics of interstitial water and overlying water in the lacustrine environment
}

\author{
Urszula Aleksander-Kwaterczak ${ }^{1} \cdot$ Robert Zdechlik $^{1}$
}

Received: 2 November 2015/Accepted: 30 September 2016/Published online: 14 October 2016

(c) The Author(s) 2016. This article is published with open access at Springerlink.com

\begin{abstract}
This research was conducted in the lacustrine environment of Lake Wigry, one of the largest and deepest lakes in Poland. The main objective was to determine the relationship between the chemical composition of interstitial water, overlying water and bottom sediment in the different sedimentation conditions. Therefore, seven research positions were selected, taking into account different zones of lake and lithological type of deposits. Overlying water samples taken from zones with carbonate type of sediment (lacustrine chalk or calcareous gyttja) were characterized by slightly alkaline $\mathrm{pH}$, similar hydrogeochemical type $\left(\mathrm{HCO}_{3}-\mathrm{Ca}-\mathrm{Mg}, \mathrm{HCO}_{3}-\right.$ $\mathrm{SO}_{4}-\mathrm{Ca}-\mathrm{Mg}$ ), low values of mineralization and low metal concentrations. The situation is different with the water taken from the zone of organic: detritus gyttja or dy deposits. Overlying water collected from the Hańczańska Bay (estuary of Czarna Hańcza River) had the highest mineralization $552 \mathrm{mg} / \mathrm{L}, \mathrm{HCO}_{3}-\mathrm{Ca}$ type and low metal concentrations, while water collected from the dystrophic lake was $\mathrm{SO}_{4}-\mathrm{Ca}-\mathrm{Mg}$ type, low mineralized and acidic type. Studies of interstitial solutions collected from different lithological type of sediments showed noticeable chemical composition differences, both between the carbonate and organic sediments in the same reservoir, as well as in the same kind of sediment but exposed to different external conditions. The highest mineralization
\end{abstract}

Urszula Aleksander-Kwaterczak

aleksa@geol.agh.edu.pl

Robert Zdechlik

robert.zdechlik@agh.edu.pl

1 AGH University of Science and Technology, 30 A. Mickiewicza Av., Krakow, Poland
(2032 mg/L) was generally found in the interstitial water obtained from the detritus gyttja localized in the shallow positions, which are more exposed to pollution. The highest trace metals and nutrients content in the sediment and interstitial water found in the Czarna Hańcza River estuary were a result of the input from increasing industrial wastewater, domestic sewage discharge and runoff from agricultural soil. A greater resistance to adsorption of contaminants characterizes sediments composed of the lacustrine chalk; mineralization of their pore solutions was significantly lower. This fact is probably also affected by very low mineralization and chemical composition of overlying water and sediment.

Keywords Lacustrine sediment - Interstitial water · Chemical composition - Lake Wigry · Dystrophic lake

\section{Introduction}

Interstitial water constitutes the link between the aquatic sediment and the overlying water, with the sediment-water interface associated with steep gradients in density, particle and solution composition, activities of chemical species, $\mathrm{pH}$, redox potential and biological activity between two phases (Santschi 1990). In the assessment of the aquatic environment, it is important to determine interactions between the direct contact separating sediment and water. For this, it is necessary to recognize the chemical composition of the interstitial water that fills the pore spaces of solid particles within sediments of a body of water.

Knowledge of the chemical composition and its temporal and spatial variation of the interstitial water may explain the origin of water and its palaeohydrogeological processes. This can prove effective in assessing conditions 
of circulation and exchange rate of groundwater as well (Szczepańska et al. 1980). It is also useful in determining sediments' participation in overlying water contamination (Aggett and O'Brien 1985). This is particularly important in the case of reservoir dredging when there is a potential risk of migration of contaminants into the water and/or their mobilization within the sediment (Brannon et al. 1980). Generally, there are two groups of factors that are the main determinants of pore water chemistry. The first factor determines the initial composition of the water at the time of the sediment formation, for example, geographical and hydrochemical environment and conditions in the reservoir. The second are the factors and processes leading to changes in the original composition of water, for example, cation exchange reactions between the interstitial water and exchangeable rocks complex, processes of diffusion, ion movement or participation of the pore water in the minerals formation (Myślińska 1974).

Mineralization and chemical composition of interstitial water depends therefore not only on the palaeogeographic conditions of their formation, but primarily on a number of physical and chemical processes occurring in the sediments from the moment of sedimentation. Among these aforementioned conditions, the most important are (Schulz 2006): substance removing within interstitial water by precipitation or adsorption and substance releasing into interstitial water from the solid phase (i.e. by dissolution or desorption or transporting of dissolved substances by diffusion within interstitial water and across the sedimentwater interface). These processes can sometimes completely change the initial composition of interstitial water. Factors that might affect the chemical bioavailability in interstitial solutions include sorption to test container surfaces and reduction through shifts in $\mathrm{pH}$ (Adams et al. 2000). Chemical bioavailability can be also reduced by organic carbon dissolved in interstitial water (Suedel et al. 1993; Williamson and Burgess 2000). Maassen et al. (2005) presented that sediment and pore water both reflect the trophic characteristic of the water body and are, in turn, also strongly affected by it. They proposed to include the tested water and sediment into common trophic evaluation systems.

The diagenetic processes in sediment are also the reason for the frequent variation of the chemical characteristics of interstitial and overlying water (Salomons et al. 1987). Interstitial water is a very sensitive indicator of diagenetic reactions occurring within the aquatic sediment and shows marked changes in chemical composition, while changes in the sediments' chemical characteristics may be unnoticeable (Berner 1980). Temporal changes in the interstitial water may also depend on seasonal changes in temperature, sedimentation rate and the biomass production (Song and Müller 1995).
The main goal of this research was to assess variations in the chemical composition of the interstitial and overlying water with regard to the lithology of sediments on the example of lacustrine environment of Lake Wigry. Lake requires special attention because of its complexity. Individual parts of this lake are strongly differentiated in terms of shape, depth and bottom sculptures and water supply, which is associated with their origins. There are also different sedimentation conditions and various external factors that may have a significant impact on the final formation of sediments, on their chemistry and chemical composition of pore solutions occurring in them. All of these make the described lake a unique and universal at the same time, in relation to other lakes of similar origin. The results can also show pore water as a very sensitive indicator pointing to pollutants degree and their transport, which could become a contribution to their use in the monitoring research.

\section{Research area}

The study was conducted in north-eastern Poland in the area of Lake Wigry located in Wigry National Park, on the border of the Eastern Suwałki Lake District and the Augustów Plain (Kondracki 1988). It is one of the largest and deepest lakes in Poland (Jańczak 1999). It consists of several parts that differ in size, depth, number of islands, chemical composition of water and the nature of shores. There are both extensive cavities, as well as, irregular or elongated ridges $(40-50 \mathrm{~m})$ there. The Czarna Hańcza and Wiatrołuża rivers determine the magnitude as well as dynamic of water flow into Lake Wigry. These rivers deliver an average of $91.7 \mathrm{hm}^{3}$ of water to the lake per year. Taking into consideration annual cycle of circulation, in the whole Lake Wigry horizontal exchange of water plays a key role. In the period of 2001-2008, Lake Wigry contained $117.829 \mathrm{hm}^{3}$ of water. River water flowing into the lake constituted $84 \%$ of all inflows and $92 \%$ of all outflows. The ratio between water flowing into the lake and water leaving the lake was 0.92 , and difference between sum of water inflow and outflow, called retention, was $0.29 \mathrm{hm} \mathrm{m}^{3}$ (Bajkiewicz-Grabowska 2009). Both the river water and the groundwater that supply the lake are rich in dissolved calcium carbonate, which comes from the dilution of Pleistocene deposits. Wigry is a dimictic lake with summer and winter stagnation and spring and autumn mixion. In the summer, epilimnion reaches to a depth of $8 \mathrm{~m}$ and metalimnion to about $12 \mathrm{~m}$. From the depth below a dozen or so meters (hypolimnion), water temperatures are fixed and do not exceed 5-6 ${ }^{\circ} \mathrm{C}$. The oxygen conditions of water are variable. During the summer stagnation period, the conditions are rather bad, and even anoxic (Rutkowski 
et al. 2007). The natural lake resistance to degradation is high due to the reservoir morphometric parameters: large surface area and volume, favourable location of the inflow in relation to the outflow and little influence on lake the nearest area of catchment. The physicochemical processes in the Czarna Hańcza River (dilution, precipitation, sedimentation of mineral and organic compounds) determine the lake water quality (Zdanowski and Hutorowicz 1997).

Both Lake Wigry and other smaller basins in the immediate vicinity of that lake have the same origin. Their present surface was mainly formed by the action of accumulation and deforming during the advance and then deglaciation of Vistulian ice sheet. Lake Wigry in the present form was formed in the Late Pleistocene due to the melting of the dead ice blocks which filled its particular basins called regionally 'plosa' (Ber 2009). Lake Wigry is an unusual, mesotrophic lake, which consists of a few basins connected by straights which together with bays and islands divide water masses into several water regions. Each region of the lake has its own unique water depth. The shape of the lake and the lake bottom is conducive to diverse habitat conditions, in particular in trophy, thermal and oxygen conditions, and water exchange (Kamiński 1999; Rutkowski et al. 2009). Research of carbon dioxide concentration showed that Lake Wigry is not a sink but is a source for the atmospheric $\mathrm{CO}_{2}$. However, an additional or significant source of $\mathrm{CO}_{2}$ to lake water can also be sediment (Paprocka and Leśniak 2008).

Sediments of Lake Wigry show a high variability and have been the object of scientific interest dating back to the beginning of the last century (e.g. Stangenberg 1938). These are mostly carbonate-organic formations (calcareous gyttjas), specific for deep areas known as the profundal zone. Pure carbonate sediments (lacustrine chalk) predominate in the littoral zone, while clastic sediment can be found close to the banks. Specific organic-reach sediment occurs locally in the Hańczańska Bay and in dystrophic lakes regionally called 'suchar'. These small brown water lakes are closed systems and are surrounded by forests (Rutkowski et al. 2002, 2003, 2009). For that type of lakes, very typical is sediment called 'dy', which is gelatinous and acidic sediment formed in anaerobic conditions by flocculation and precipitation from dissolved large and insoluble particles of humus materials. Its thickness reaches few meters or more (Huggett 2007; Drzymulska et al. 2014). To assess determination of dystrophy level in 'suchar' polyhumic lakes in Wigry National Park, new limnological index-Hydrochemical Dystrophy Index, HDI-was used (Górniak 2004), which is calculated from $\mathrm{pH}$, EC, DIC and DOC in surface water. When $H D I$ values are higher than 50, dystrophic conditions occur.

\section{Methods}

To assess the variations in the chemical composition of interstitial and overlying water (near the sediment-water interface), seven sampling positions were selected (Fig. 1), taking into account different zones (littoral, profundal and dystrophic) and lithological type of deposits (Table 1). A specific sampling point (W-5) was located in the mixing zone of the water (contaminated by the Czarna Hańcza River with relatively clear water of Lake Wigry). The point W-3 was used for the assessment of hydrogeochemical conditions occurring in dystrophic lakes, which occur in the vicinity of Lake Wigry in relatively large amounts.

Samples of sediment and overlying water were collected from individual points in the area of Lake Wigry. Samples of bottom sediment were taken by a gravity sampler, which allows cores of different lengths (from 30 to $100 \mathrm{~cm}$ ) to be taken depending on local conditions (Figs. 2, 3, 4, 5). Locations were determined by GPS and the water depth by using an echosounder (FCV, Furuno). Sediment cores were sliced into segments $(5,10,15$ or $20 \mathrm{~cm})$ according to the lithology. Three to four sediment samples were taken from each position. In total, 25 sediment samples and 7 water samples were collected. Interstitial water was isolated by the centrifugation method, using a laboratory centrifuge (Beckman) with a rotor placed in the horizontal plane. Centrifugation was performed at $3000 \mathrm{rpm}$ for $20 \mathrm{~min}$.

The analyses of water chemical composition were conducted at the Hydrogeochemical Laboratory in the Department of Hydrogeology and Engineering Geology at Faculty of Geology, Geophysics and Environmental Protection, AGH University of Science and Technology in Kraków. They were performed according to the standard certified analytical quality control procedure. Reagent blanks and certified reference materials were used to control the analytical accuracy. Results from the ICP-MS method were confirmed with F-AAS measurements, which attested to the very good analytical quality of all analysed elements.

The water samples' $\mathrm{pH}$, cations $\left(\mathrm{Na}^{+}, \mathrm{K}^{+}, \mathrm{Ca}^{2+}, \mathrm{Mg}^{2+}\right.$, $\left.\mathrm{Fe}^{2+}, \mathrm{Mn}^{2+}, \mathrm{Zn}^{2+}, \mathrm{Co}^{2+}, \mathrm{Pb}^{2+}, \mathrm{Cd}^{2+}, \mathrm{Cr}^{3+}\right)$ and anions $\left(\mathrm{Cl}^{-}, \mathrm{SO}_{4}{ }^{2-}, \mathrm{HCO}_{3}{ }^{2-}, \mathrm{PO}_{4}{ }^{3-}, \mathrm{NO}_{3}{ }^{-}\right)$were indicated according to the methodology given in Table 2. The hydrogeochemical type of water was also determined (Figs. 2, 3, 4, 5) in accordance with the SzczukariewPriklonski classification (Alekin 1970).

\section{Results and discussion}

\section{Lithological types of sediments}

The first type of samples constitutes carbonate sedimentlacustrine chalk. It was identified in Ploso Bryzglowskie 


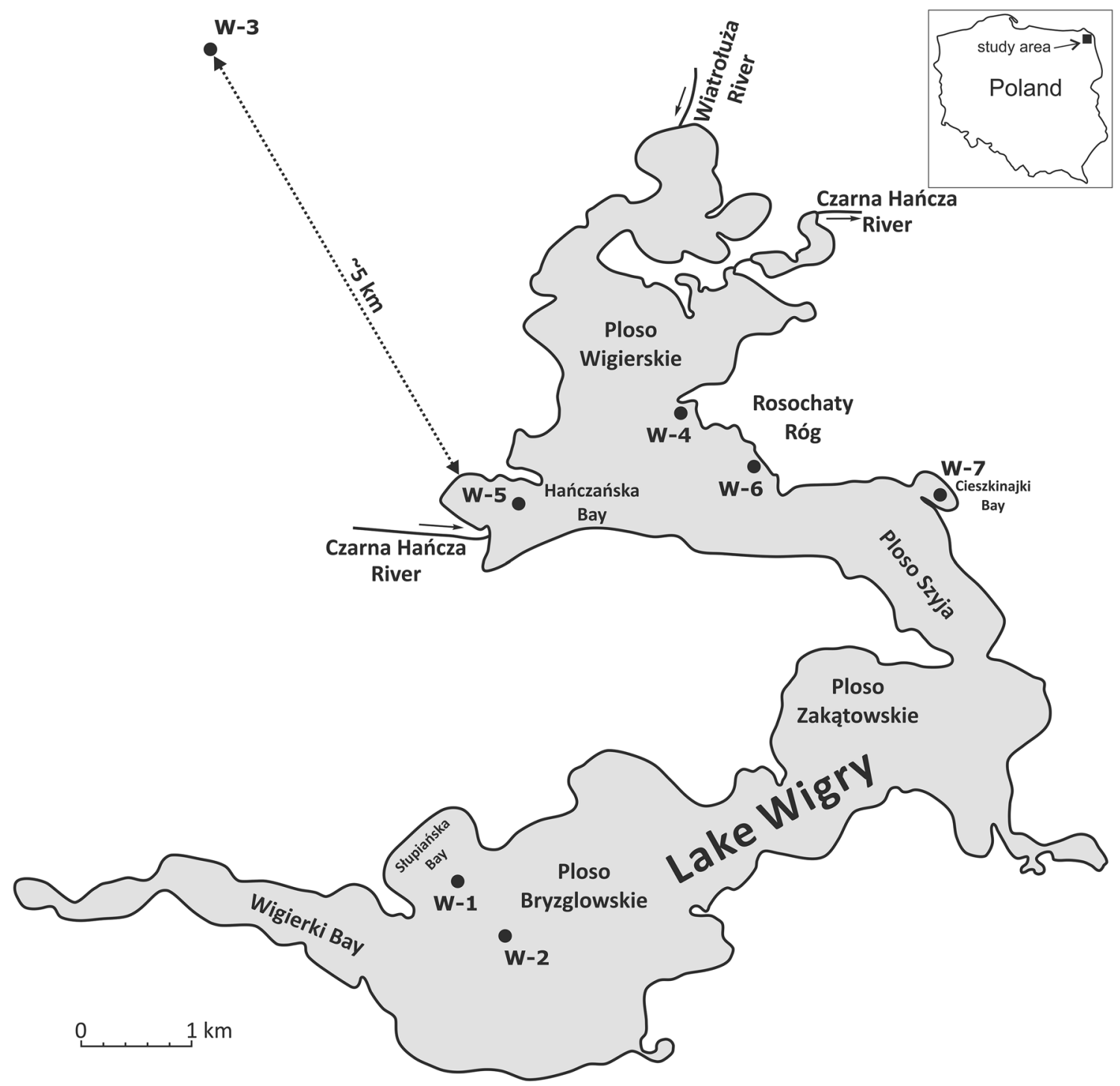

Fig. 1 Locations of sediments and overlying water sampling points

Table 1 Characterization of sediments and overlying water sampling points

\begin{tabular}{lll}
\hline Type of sediment & Sampling point & Location $^{*}$ \\
\hline Lacustrine chalk & W-2 & Ploso Bryzglowskie \\
& W-6 & Rosochaty Róg \\
Calcareous gyttja & W-1 & Słupiańska Bay \\
& W-4 & bay in Rosochaty Róg \\
& W-7 & Cieszkinajki Bay \\
Detritus gyttja & W-5 & Hańczańska Bay \\
Dy & W-3 & Suchar-dystrophic lake \\
\hline
\end{tabular}

* According to Fig. 1

(W-2) and Rosochaty Róg (W-6) (Fig. 1) and had the typical features as described by Rutkowski et al. (2009). It had a bright colour, large contents of clay and silt grain size-fraction which results in poor permeability for water, a relatively high bulk density $\left(1.4-1.5 \mathrm{~g} / \mathrm{cm}^{3}\right)$ and the high content $(>90 \%)$ of calcium carbonate in the form of limestone dust and irregular lumps. Apart from the calcium carbonate, the main component of this sediment was organic substance and quartz.

In the analysed bays, the gyttja samples were found. In Słupiańska Bay (W-1), bay in Rosochaty Róg (W-4) and Cieszkinajki Bay (W-7) (Fig. 1), it was calcareous gyttja. The main component of samples is typical for such sediment in Lake Wigry (Rutkowski et al. 2009); it was also calcium carbonate, but the amount (54-87\%) was less than in lacustrine chalk and organic matter (about $10 \%$ ). They were very fine grained, resulting in their low permeability. Their water content was very high (75.6-95.6\%) and significantly higher than in the lacustrine chalk; however, 

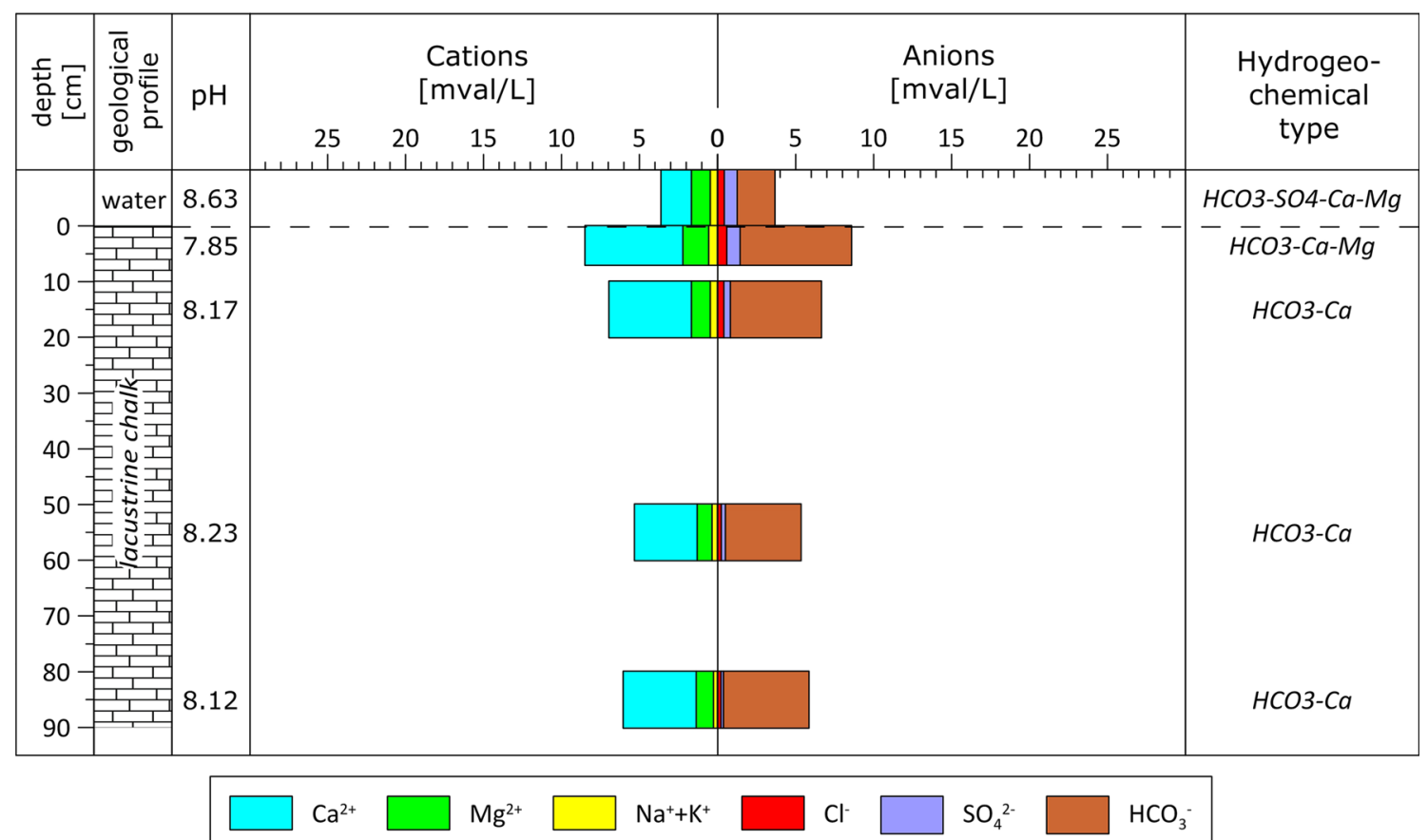

$W$-2 sampling point

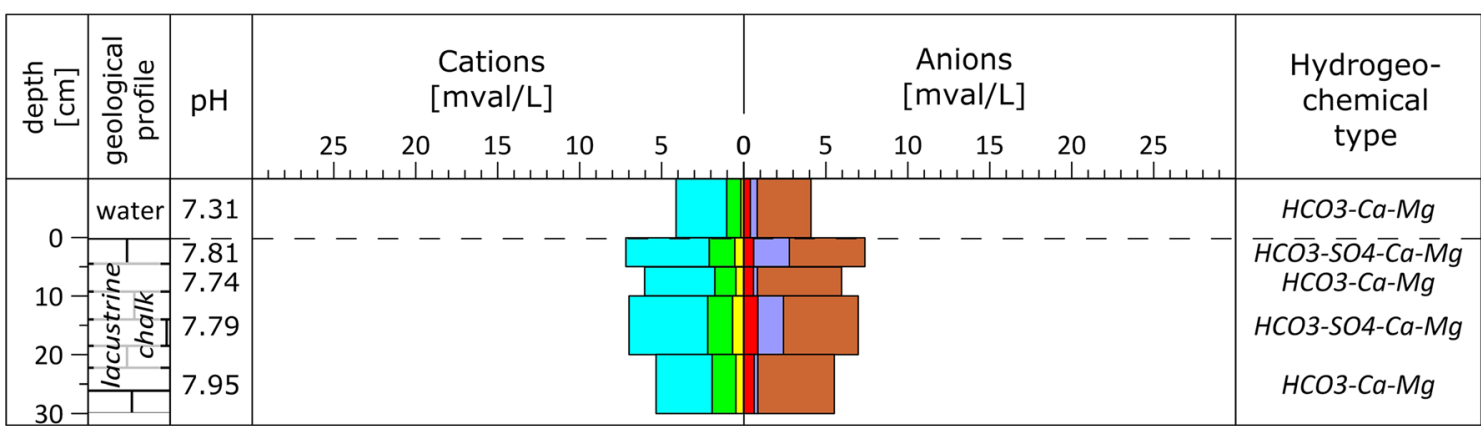

$\square \mathrm{Ca}^{2+} \square \mathrm{Mg}^{2+} \square \mathrm{Na}^{+}+\mathrm{K}^{+} \square \mathrm{Cl}^{-} \square \mathrm{SO}_{4}^{2-} \square \mathrm{HCO}_{3}$

\section{$W$-6 sampling point}

Fig. 2 Variation of chemical composition of the overlying water and interstitial water in the vertical profile of lacustrine chalk type of sediments from Lake Wigry

in contrast, their bulk density was very low: $1.05-1.24 \mathrm{~g} /$ $\mathrm{cm}^{3}$. In water separated from these deposits, lower concentrations of calcium and magnesium ions were indicated and connected therewith even slightly lower $\mathrm{pH}$. Additionally, in the profundal zone a high iron and magnesium contents can be seen, which could indicate an enrichment of these metals that are abundant in groundwater, or about the diagenetic processes taking place in the sediments (Salomons and Förstner 1984).

Lake sediment formed directly at the mouth of the Czarna Hańcza River (Hańczańska Bay, W-5, Fig. 1) was described by Rutkowski et al. (2009) as detritus gyttja. It had specific character: it was built from the remains of plants and has high water content (84.4-91.4\%), low bulk density (1.01-1.05 g/ $\left./ \mathrm{cm}^{3}\right)$ and low (3.0-13.4\%) $\mathrm{CaCO}_{3}$ concentration. In these deposits, the influences of pollutants carried with the river were indicated (AleksanderKwaterczak and Prosowicz 2007).

'Suchar' is a small dystrophic lake, isolated and without outflow, formed by the melting of blocks of ice during the last ice age (Rutkowski et al. 2009). Sediment samples known as dy were brown in colour and heavily hydrated in surface layers. These were pure organic deposits built with humic acids resulting from the decomposition of organic material and with the absence or a slight admixture of calcium carbonate. Lake with W-3 point (Fig. 1), which 


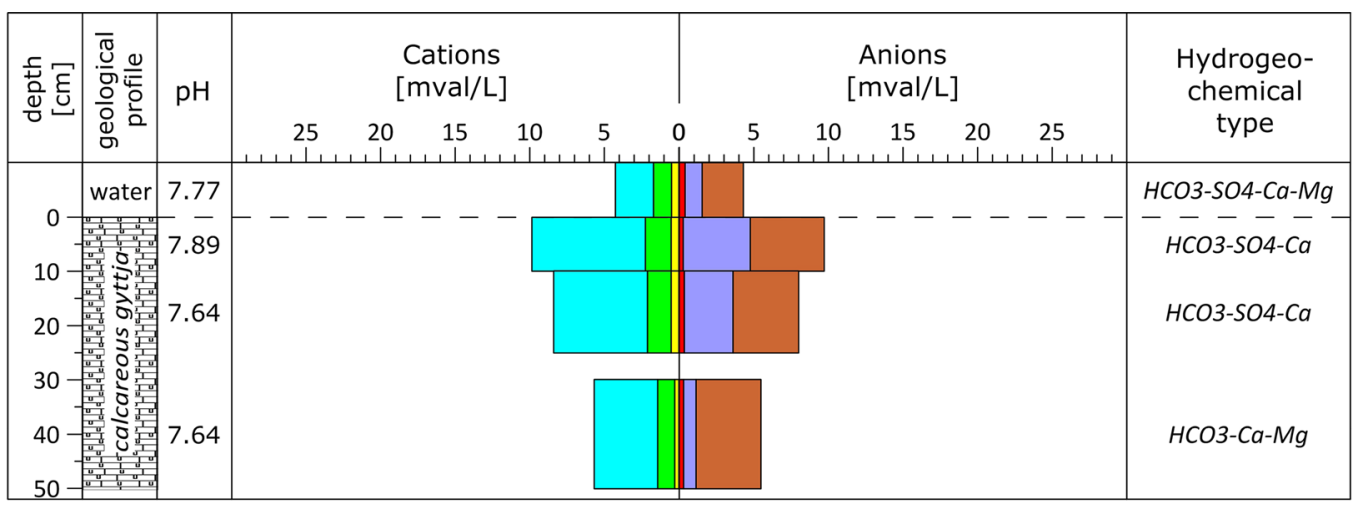

$\mathrm{Ca}^{2+} \square \mathrm{Mg}^{2+} \square \mathrm{Na}^{++}+\mathrm{K}^{+} \square \mathrm{Cl}^{-} \square \mathrm{SO}_{4}{ }^{2-} \square \mathrm{HCO}_{3}^{-}$

$W-1$ sampling point

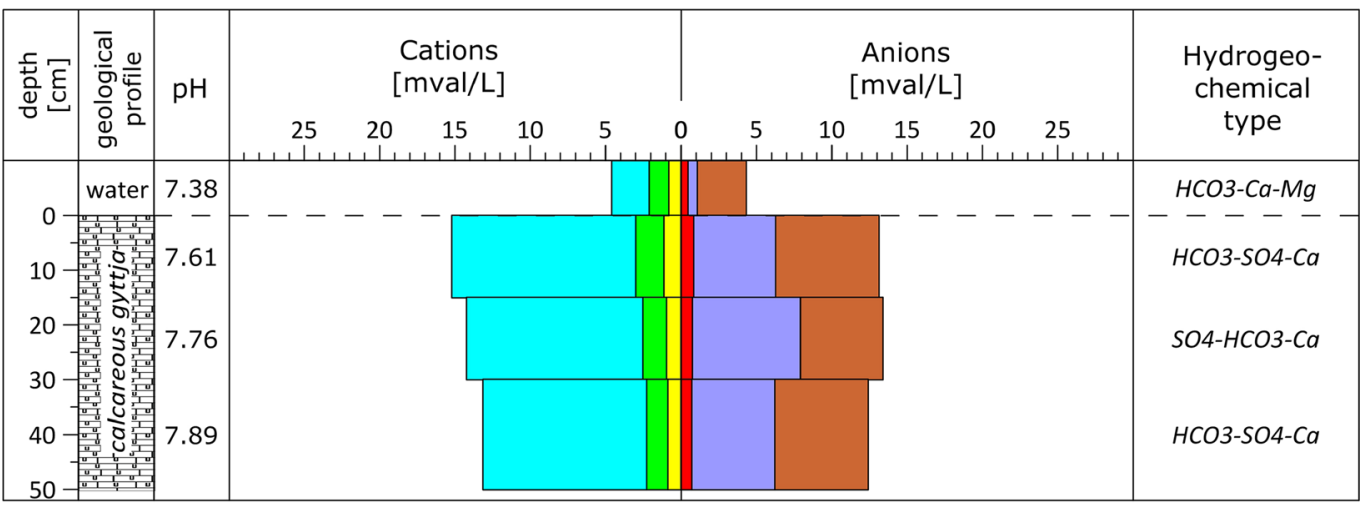

$\square \mathrm{Ca}^{2+} \square \mathrm{Mg}^{2+} \square \mathrm{Na}^{+}+\mathrm{K}^{+} \square \mathrm{Cl}^{-} \square \mathrm{SO}_{4}^{2-} \square \mathrm{HCO}_{3}$

$W-4$ sampling point

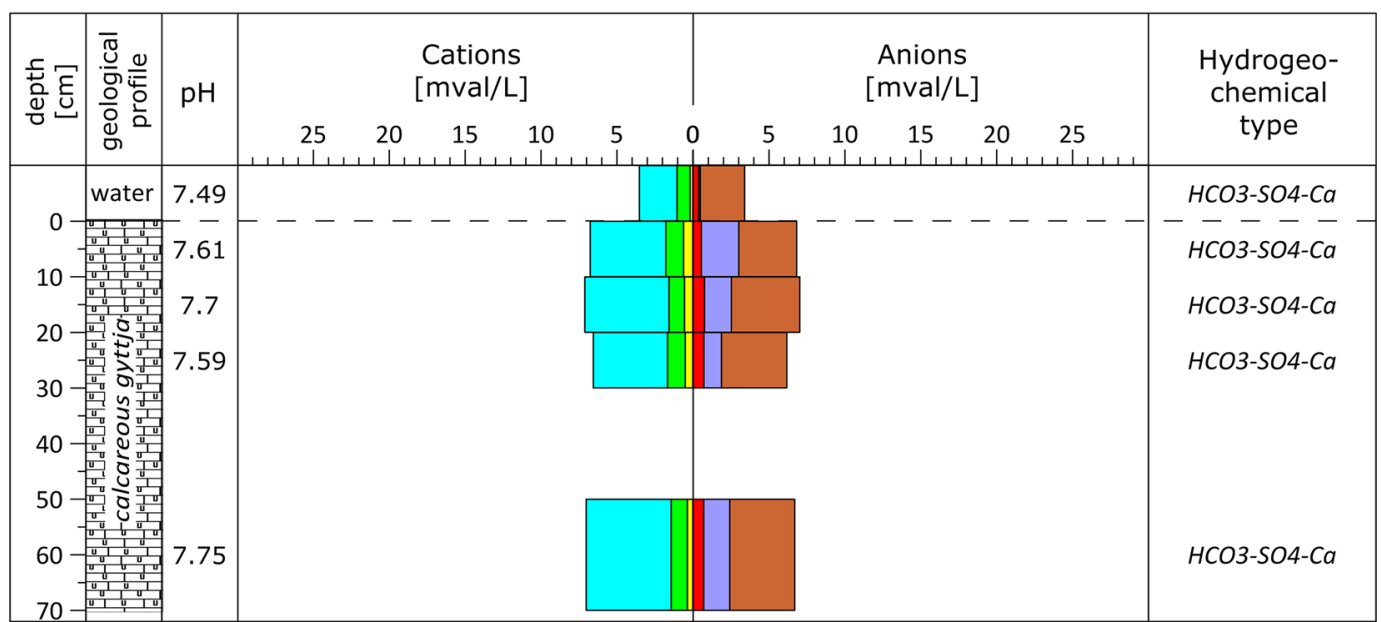

$\square \mathrm{Ca}^{2+} \square \mathrm{Mg}^{2+} \square \mathrm{Na}^{+}+\mathrm{K}^{+} \square \mathrm{Cl}^{-} \square \mathrm{SO}_{4}{ }^{2-} \square \mathrm{HCO}_{3}$

$W-7$ sampling point

Fig. 3 Variation of chemical composition of the overlying water and interstitial water in the vertical profile of calcareous gyttja type of sediments from Lake Wigry 


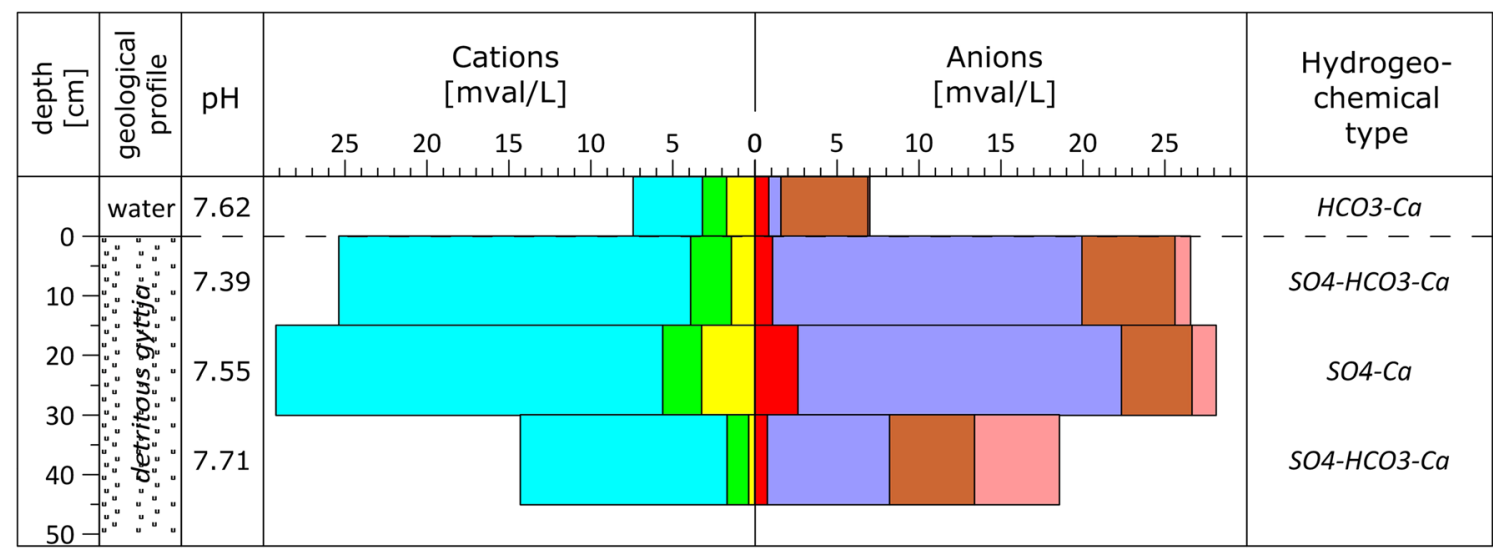

$\square \mathrm{Ca}^{2+} \square \mathrm{Mg}^{2+} \square \mathrm{Na}^{+}+\mathrm{K}^{+} \square \mathrm{Cl}^{-} \square \mathrm{SO}_{4}^{2-} \square \mathrm{HCO}_{3}^{-} \square \mathrm{NO}_{3}^{-}$

$W-5$ sampling point

Fig. 4 Variation of chemical composition of the overlying water and interstitial water in vertical profile of detritus gyttja type of sediments from Lake Wigry

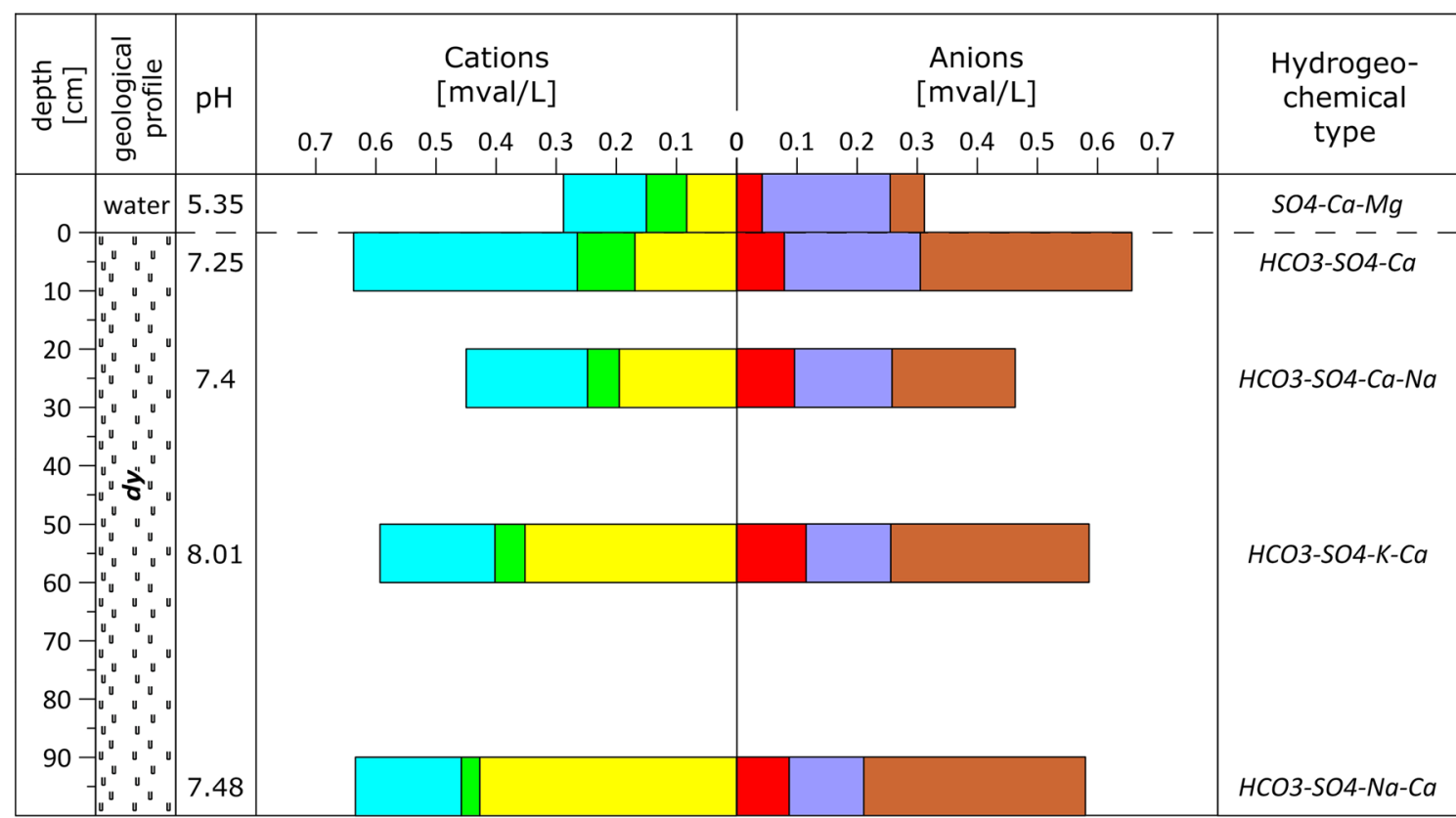

$\square \mathrm{Ca}^{2+} \square \mathrm{Mg}^{2+} \square \mathrm{Na}^{+}+\mathrm{K}^{+} \square \mathrm{Cl}^{-} \square \mathrm{SO}_{4}^{2-} \square \mathrm{HCO}_{3}^{-}$

$W-3$ sampling point

Fig. 5 Variation of chemical composition of the overlying water and interstitial water in the vertical profile of dy type of sediments from dystrophic lake ('suchar') 
Table 2 Methods of physicochemical parameters determinations

\begin{tabular}{lll}
\hline Parameter & Method & \\
\hline $\mathrm{pH}$ & Potentiometric & PN-C-04540-01:1990 \\
Ions concentration & Inductively Coupled Plasma-Mass & PN-EN ISO 17294-2:2006; \\
& Spectrometry (ICP-MS) & PN-EN ISO 17294-1:2007 \\
Chlorides & Titration (Mohr method) & PN-EN ISO 9297:1994 \\
Nitrates & Spectrophotometric & PN-C-04576-08:1982 \\
Alkalinity & Titration & PN-EN ISO 9963-1:2001+Ap1:2004 \\
\hline
\end{tabular}

according to Górniak (2004) is 'Suchar III', had the most dystrophic conditions $(H D I=121)$.

\section{Hydrochemical characteristic of overlying water}

Values of the main physical and chemical parameters (Tables 3,4) were determined using basic statistical characteristics. There are many methods of statistical analysis for environmental data with low, below the limit of detection, values. The best-known statistical techniques were compared by Antweiler and Taylor (2008), assuming that the data sets have less than $70 \%$ censored data. In the cases at high degrees of censoring, this is greater than $70 \%$ censored data; no technique provided good estimates of summary statistics.

In the case of results presented in the paper, according to Commission Directive 2009/90/EC, during the calculations of mean values, for metals (Table 4) all data below the detection limits (DL) were set to half of these limits values $(1 / 2 \mathrm{DL})$. The data used are archival, and there is not a possibility to present them in the uncensored form. At the same time, the applied method of proceeding does not play a major role, as detection limits adopted are, in general, low and do not affect the overall water quality classification.

Overlying water samples taken from zones with lacustrine chalk type of sediment were characterized by slightly alkaline $\mathrm{pH}$ (8.63 in $\mathrm{W}-2$ and 7.31 in $\mathrm{W}-6$; Table 3; Fig. 2). They had a similar hydrogeochemical type: $\mathrm{HCO}_{3}-$ $\mathrm{Ca}-\mathrm{Mg}$ in Rosochaty Róg (W-6) and $\mathrm{HCO}_{3}-\mathrm{SO}_{4}-\mathrm{Ca}-\mathrm{Mg}$ in Ploso Bryzglowskie (W-2) and low values of mineralization $(270-314 \mathrm{mg} / \mathrm{L})$. There was also very low metals concentration in them (Table 4).

Chemical composition of the overlying water taken from zones above the calcareous gyttja sediments (W-1, W-4 and W-7; Table 3; Fig. 3) was similar to that from above lacustrine chalk. These were multi-ion water of $\mathrm{HCO}_{3}-$ $\mathrm{SO}_{4}-\mathrm{Ca}-\mathrm{Mg}, \mathrm{HCO}_{3}-\mathrm{Ca}-\mathrm{Mg}$ or $\mathrm{HCO}_{3}-\mathrm{SO}_{4}-\mathrm{Ca}$ type. They had a low mineralization $(268-334 \mathrm{mg} / \mathrm{L})$ and were weakly alkaline ( $\mathrm{pH}$ from 7.38 to 7.77 ). Generally, the slightly higher metal concentrations were found compares with water collected from lacustrine chalk zone (Table 4).
The situation was different with the composition of the water taken from the zone of detritus gyttja deposits (Table 3). Overlying water collected from Hańczańska Bay (W-5, Fig. 4) had the highest mineralization $552 \mathrm{mg} / \mathrm{L}$, $\mathrm{HCO}_{3}-\mathrm{Ca}$ type and low metal concentrations, while water from the dystrophic lake (W-3, Fig. 5) of $\mathrm{SO}_{4}-\mathrm{Ca}-\mathrm{Mg}$ type was low mineralized $(28 \mathrm{mg} / \mathrm{L})$ and acidic $(\mathrm{pH}=5.35)$. Natural acidification is caused by accumulation of the humus substances and the absence of inflows. There are very good conditions to higher metal concentration in the mobile fractions, especially in the oxides and hydroxides of iron or the organic matter fraction (Kļavins et al. 1995; Cudowski 2015) and their migration into overlying water.

\section{Hydrogeochemical characterization of interstitial water in sediment cores}

Hydrogeochemical background values were used for the physicochemical composition assessment of interstitial water. It is a range of concentrations of the analysed substance or a range of hydrochemical features values, which is characteristic for a particular environment and is limited by the lower and upper limits of concentration beyond which are anomalous values (Dowgiałło et al. 2002). The limit values of hydrogeochemical background (Table 5) were determined as a probability of $16 \%$ percentile as lower limit and $84 \%$ percentile as upper limit (according to Szczepańska and Kmiecik 2005). This procedure is the most often used in Poland and allows the comparison of own results with the results obtained for other locations.

The values of the hydrogeochemical background were determined also for selected metal ions $\left(\mathrm{Fe}^{2+}, \mathrm{Mn}^{2+}, \mathrm{Zn}^{2+}\right.$, $\left.\mathrm{Co}^{2+}, \mathrm{Pb}^{2+}, \mathrm{Cd}^{2+}, \mathrm{Cr}^{3+}\right)$, using the statistical method (Table 6). As described above (according 2009/90/EC) during the calculations for mean values of metal, data below detection limit (DL) were changed to half value of limit (1/2 DL).

Differences in physical and chemical composition were found between interstitial and overlying water in every individual position. Generally, some differences were found between the water chemical composition of the 
Table 3 Statistical characteristic of the main physical and chemical parameters of overlying water

\begin{tabular}{|c|c|c|c|c|}
\hline Parameter & Type of sediment* & Min & Max & Mean value \\
\hline \multirow[t]{4}{*}{$\mathrm{pH}$} & Lacustrine chalk & 7.31 & 8.63 & - \\
\hline & Calcareous gyttja & 7.38 & 7.77 & - \\
\hline & Detritus gyttja & 7.62 & 7.62 & - \\
\hline & Dy & 5.35 & 5.35 & - \\
\hline \multirow[t]{4}{*}{ Mineralization [mg/L] } & Lacustrine chalk & 270.6 & 314.3 & 292.5 \\
\hline & Calcareous gyttja & 268.1 & 334.0 & 309.6 \\
\hline & Detritus gyttja & 552.3 & 552.3 & 552.3 \\
\hline & Dy & 28.0 & 28.0 & 28.0 \\
\hline \multirow[t]{4}{*}{$\mathrm{Ca}^{2+}[\mathrm{mg} / \mathrm{L}]$} & Lacustrine chalk & 39.16 & 61.83 & 50.50 \\
\hline & Calcareous gyttja & 49.60 & 51.37 & 50.25 \\
\hline & Detritus gyttja & 84.76 & 84.76 & 84.76 \\
\hline & Dy & 2.76 & 2.76 & 2.76 \\
\hline \multirow[t]{4}{*}{$\mathrm{Mg}^{2+}[\mathrm{mg} / \mathrm{L}]$} & Lacustrine chalk & 10.38 & 14.80 & 12.59 \\
\hline & Calcareous gyttja & 10.44 & 16.05 & 13.68 \\
\hline & Detritus gyttja & 17.89 & 17.89 & 17.89 \\
\hline & Dy & 0.81 & 0.81 & 0.81 \\
\hline \multirow[t]{4}{*}{$\mathrm{Na}^{+}[\mathrm{mg} / \mathrm{L}]$} & Lacustrine chalk & 3.15 & 8.80 & 5.98 \\
\hline & Calcareous gyttja & 3.19 & 16.05 & 9.30 \\
\hline & Detritus gyttja & 33.81 & 33.81 & 33.81 \\
\hline & Dy & 0.50 & 0.50 & 0.50 \\
\hline \multirow[t]{4}{*}{$\mathrm{K}^{+}[\mathrm{mg} / \mathrm{L}]$} & Lacustrine chalk & 1.38 & 2.76 & 2.07 \\
\hline & Calcareous gyttja & 1.67 & 4.87 & 3.38 \\
\hline & Detritus gyttja & 9.87 & 9.87 & 9.87 \\
\hline & Dy & 2.37 & 2.37 & 2.37 \\
\hline \multirow[t]{4}{*}{$\mathrm{Cl}^{-}[\mathrm{mg} / \mathrm{L}]$} & Lacustrine chalk & 14.0 & 15.1 & 14.6 \\
\hline & Calcareous gyttja & 13.2 & 16.4 & 14.5 \\
\hline & Detritus gyttja & 29.9 & 29.9 & 29.9 \\
\hline & Dy & 1.50 & 1.50 & 1.50 \\
\hline \multirow[t]{4}{*}{$\mathrm{SO}_{4}^{2-}[\mathrm{mg} / \mathrm{L}]$} & Lacustrine chalk & 20.0 & 39.5 & 29.8 \\
\hline & Calcareous gyttja & 5.0 & 55.4 & 29.9 \\
\hline & Detritus gyttja & 35.6 & 35.6 & 35.6 \\
\hline & Dy & 10.2 & 10.2 & 10.2 \\
\hline \multirow[t]{4}{*}{$\mathrm{HCO}_{3}{ }^{-}[\mathrm{mg} / \mathrm{L}]$} & Lacustrine chalk & 147.6 & 200.0 & 173.8 \\
\hline & Calcareous gyttja & 167.9 & 198.0 & 181.3 \\
\hline & Detritus gyttja & 324.0 & 324.0 & 324.0 \\
\hline & Dy & 3.5 & 3.5 & 3.5 \\
\hline \multirow[t]{4}{*}{$\mathrm{PO}_{4}^{3-}[\mathrm{mg} / \mathrm{L}]$} & Lacustrine chalk & 0.03 & 0.03 & 0.03 \\
\hline & Calcareous gyttja & 0.05 & 0.06 & 0.06 \\
\hline & Detritus gyttja & 0.13 & 0.13 & 0.13 \\
\hline & Dy & 0.12 & 0.12 & 0.12 \\
\hline
\end{tabular}

* Sampling points-see Table 1 carbonate and from organic sediments, which was also confirmed in the studies of Woroniecka-Stasiak (1980).

There was just a slight difference in $\mathrm{pH}$ values for water samples taken from lacustrine chalk zones (W-2 and W6; Table 5; Fig. 2). Such sediment characteristic was reflected in interstitial water composition. Water had high $\mathrm{pH}$ values (from 7.74 to 8.23); however, there was a slight
$\mathrm{pH}$ increase as the depth increased, whereas in samples from $\mathrm{W}-2$ position, the $\mathrm{pH}$ values variation with depth was irregular.

Interstitial water in samples of lacustrine chalk had a low content of calcium and magnesium and a relatively low mineralization. In such environmental conditions, most metals are precipitated and exist in the forms associated 
Table 4 Statistical characteristic of selected heavy metals in overlying water

\begin{tabular}{|c|c|c|c|c|}
\hline Parameter & Type of sediment* & Min & Max & Mean value \\
\hline \multirow[t]{4}{*}{$\mathrm{Fe}^{2+}[\mathrm{mg} / \mathrm{L}]$} & Lacustrine chalk & $<0.010$ & 0.030 & 0.020 \\
\hline & Calcareous gyttja & 0.018 & 0.021 & 0.020 \\
\hline & Detritus gyttja & 0.177 & 0.177 & 0.177 \\
\hline & Dy & 0.749 & 0.749 & 0.749 \\
\hline \multirow[t]{4}{*}{$\mathrm{Mn}^{2+}[\mathrm{mg} / \mathrm{L}]$} & Lacustrine chalk & $<0.003$ & $<0.003$ & $<0.003$ \\
\hline & Calcareous gyttja & $<0.003$ & 0.027 & 0.010 \\
\hline & Detritus gyttja & 0.014 & 0.014 & 0.014 \\
\hline & Dy & 0.085 & 0.085 & 0.085 \\
\hline \multirow[t]{4}{*}{$\mathrm{Zn}^{2+}[\mathrm{mg} / \mathrm{L}]$} & Lacustrine chalk & 0.0012 & 0.0024 & 0.0018 \\
\hline & Calcareous gyttja & 0.0016 & 0.0064 & 0.0036 \\
\hline & Detritus gyttja & 0.011 & 0.011 & 0.011 \\
\hline & Dy & 0.019 & 0.019 & 0.019 \\
\hline \multirow[t]{4}{*}{$\mathrm{Co}^{2+}[\mathrm{mg} / \mathrm{L}]$} & Lacustrine chalk & $<0.0002$ & $<0.0002$ & $<0.0002$ \\
\hline & Calcareous gyttja & $<0.0002$ & $<0.0002$ & $<0.0002$ \\
\hline & Detritus gyttja & 0.0005 & 0.0005 & 0.0005 \\
\hline & Dy & $<0.0002$ & $<0.0002$ & $<0.0002$ \\
\hline \multirow[t]{4}{*}{$\mathrm{Pb}^{2+}[\mathrm{mg} / \mathrm{L}]$} & Lacustrine chalk & $<0.0001$ & $<0.0001$ & $<0.0001$ \\
\hline & Calcareous gyttja & $<0.0001$ & $<0.0001$ & $<0.0001$ \\
\hline & Detritus gyttja & 0.0003 & 0.0003 & 0.0003 \\
\hline & Dy & 0.0006 & 0.0006 & 0.0006 \\
\hline \multirow[t]{4}{*}{$\mathrm{Cd}^{2+}[\mathrm{mg} / \mathrm{L}]$} & Lacustrine chalk & $<0.0003$ & $<0.0003$ & $<0.0003$ \\
\hline & Calcareous gyttja & $<0.0003$ & $<0.0003$ & $<0.0003$ \\
\hline & Detritus gyttja & $<0.0003$ & $<0.0003$ & $<0.0003$ \\
\hline & Dy & $<0.0003$ & $<0.0003$ & $<0.0003$ \\
\hline \multirow[t]{4}{*}{$\mathrm{Cr}^{3+}[\mathrm{mg} / \mathrm{L}]$} & Lacustrine chalk & $<0.005$ & $<0.005$ & $<0.005$ \\
\hline & Calcareous gyttja & $<0.005$ & $<0.005$ & $<0.005$ \\
\hline & Detritus gyttja & $<0.005$ & $<0.005$ & $<0.005$ \\
\hline & Dy & $<0.005$ & $<0.005$ & $<0.005$ \\
\hline
\end{tabular}

* Sampling points—see Table 1 with the solid phase; hence, their concentrations in water are very low. Hydrogeochemical types of water were similar-predominant ions are $\mathrm{Ca}^{2+}, \mathrm{SO}_{4}^{2-}$ and $\mathrm{HCO}_{3}{ }^{-}$; hence, the most common type of water was $\mathrm{HCO}_{3}-\mathrm{Ca}$, $\mathrm{HCO}_{3}-\mathrm{Ca}-\mathrm{Mg}$ or $\mathrm{HCO}_{3}-\mathrm{SO}_{4}-\mathrm{Ca}-\mathrm{Mg}$. Concentrations of analysed metals in water were very low, lower if compared with other analysed type of sediments (Table 6), which can be connected with alkaline environment (Salomons and Frstner 1984; Elder 1989; Salomons 1995; Wällstedt and Borg 2003) and low metals concentration in carbonate sediments of Lake Wigry (Aleksander-Kwaterczak et al. 2009; Prosowicz et al. 2009; Aleksander-Kwaterczak and Kostka 2011).

The $\mathrm{pH}$ of the interstitial water collected from calcareous gyttja samples (Table 5; Fig. 3) was very similar and changed in the range from 7.59 to 7.89 . There was also just a slight increase in the $\mathrm{pH}$ values in relation to overlying water and a general increase of $\mathrm{pH}$ with the increasing sediment depth. A large variation of mineralization was determined: from lower values founded for the solutions from $\mathrm{W}-1$ positions $-479 \mathrm{mg} / \mathrm{L}$ in the depth from 30 to $50 \mathrm{~cm}$, to $1119 \mathrm{mg} / \mathrm{L}$ in the depth from surface to $15 \mathrm{~cm}$ in the $\mathrm{W}-4$ position. The mineralization differed slightly in the $\mathrm{W}-7$ position (from 512 to $580 \mathrm{mg}$ / $\mathrm{L})$. In the position of $\mathrm{W}-1$, mineralization decreased with depth from $762 \mathrm{mg} / \mathrm{L}$ to $479 \mathrm{mg} / \mathrm{L}$. Interstitial water samples were more homogeneous in terms of their chemical type; the dominant type was $\mathrm{HCO}_{3}-\mathrm{SO}_{4}-\mathrm{Ca}$ and only in $\mathrm{W}-1$ position in the depth from 30 to $50 \mathrm{~cm} \mathrm{HCO}_{3}-\mathrm{Ca}-$ $\mathrm{Mg}$ type of water occurred.

Samples collected from calcareous gyttja had the highest concentrations of $\mathrm{Fe}^{2+}$ ions (mean value $0.156 \mathrm{mg} / \mathrm{L}$, Table 6). Samples from calcareous gyttja statistically hold the highest mean concentrations of $\mathrm{Mn}^{2+}(0.162 \mathrm{mg} / \mathrm{L})$, $\mathrm{Zn}^{2+}(0.04 \mathrm{mg} / \mathrm{L}), \mathrm{Co}^{2+}(0.0004 \mathrm{mg} / \mathrm{L}), \mathrm{Pb}^{2+}(0.0026 \mathrm{mg} /$ $\mathrm{L}), \mathrm{Cr}^{3+}(0.008 \mathrm{mg} / \mathrm{L})$ and $\mathrm{Cd}^{2+}(0.00033 \mathrm{mg} / \mathrm{L})$.

The chemical composition of interstitial water collected from detritus gyttja in Hańczańska Bay varied as 
Table 5 Hydrogeochemical background values of the main physical and chemical parameters of interstitial water

\begin{tabular}{|c|c|c|c|c|c|c|c|}
\hline Parameter & Type of sediment* & Min & Max & Interval & Mean value & Percentile $16 \%$ & Percentile $84 \%$ \\
\hline \multirow[t]{4}{*}{$\mathrm{pH}$} & Lacustrine chalk & 7.74 & 8.23 & 0.49 & - & 7.79 & 8.16 \\
\hline & Calcareous gyttja & 7.59 & 7.89 & 0.30 & - & 7.61 & 7.83 \\
\hline & Detritus gyttja & 7.39 & 7.71 & 0.32 & - & 7.44 & 7.66 \\
\hline & Dy & 7.25 & 8.01 & 0.76 & - & 7.32 & 7.76 \\
\hline \multirow[t]{4}{*}{ Mineralization [mg/L] } & Lacustrine chalk & 445.6 & 711.6 & 266.0 & 544.5 & 481.3 & 586.7 \\
\hline & Calcareous gyttja & 479.0 & 1118.7 & 639.7 & 717.7 & 522.6 & 997.0 \\
\hline & Detritus gyttja & 1102.4 & 2031.7 & 929.3 & 1670.9 & 1350.8 & 1982.7 \\
\hline & Dy & 49.5 & 69.1 & 19.6 & 61.4 & 55.2 & 67.4 \\
\hline \multirow[t]{4}{*}{$\mathrm{Ca}^{2+}[\mathrm{mg} / \mathrm{L}]$} & Lacustrine chalk & 68.4 & 126.0 & 57.7 & 94.9 & 81.3 & 105.8 \\
\hline & Calcareous gyttja & 85.4 & 245.0 & 159.6 & 148.3 & 98.9 & 227.2 \\
\hline & Detritus gyttja & 252.9 & 472.7 & 219.8 & 385.3 & 309.7 & 459.1 \\
\hline & Dy & 3.5 & 7.5 & 3.9 & 4.7 & 3.7 & 5.8 \\
\hline \multirow[t]{4}{*}{$\mathrm{Mg}^{2+}[\mathrm{mg} / \mathrm{L}]$} & Lacustrine chalk & 11.5 & 20.0 & 8.6 & 16.3 & 13.5 & 18.9 \\
\hline & Calcareous gyttja & 12.3 & 22.8 & 10.5 & 16.7 & 13.3 & 20.3 \\
\hline & Detritus gyttja & 16.1 & 30.2 & 14.2 & 25.1 & 20.2 & 29.8 \\
\hline & Dy & 0.4 & 1.2 & 0.8 & 0.7 & 0.5 & 0.9 \\
\hline \multirow[t]{4}{*}{$\mathrm{Na}^{+}[\mathrm{mg} / \mathrm{L}]$} & Lacustrine chalk & 3.8 & 14.1 & 10.4 & 8.8 & 5.3 & 10.7 \\
\hline & Calcareous gyttja & 5.1 & 22.8 & 17.7 & 11.6 & 6.6 & 18.4 \\
\hline & Detritus gyttja & 7.1 & 28.9 & 21.8 & 20.7 & 13.2 & 28.0 \\
\hline & Dy & 1.9 & 8.4 & 6.4 & 3.7 & 1.9 & 5.6 \\
\hline \multirow[t]{4}{*}{$\mathrm{K}^{+}[\mathrm{mg} / \mathrm{L}]$} & Lacustrine chalk & 2.1 & 5.3 & 3.1 & 3.5 & 2.3 & 5.0 \\
\hline & Calcareous gyttja & 2.4 & 6.3 & 3.9 & 4.7 & 3.9 & 5.8 \\
\hline & Detritus gyttja & 2.3 & 77.8 & 75.5 & 30.4 & 5.1 & 56.5 \\
\hline & Dy & 2.5 & 10.5 & 8.0 & 4.9 & 2.8 & 7.1 \\
\hline \multirow[t]{4}{*}{$\mathrm{Cl}^{-}[\mathrm{mg} / \mathrm{L}]$} & Lacustrine chalk & 7.6 & 30.3 & 22.7 & 18.1 & 9.0 & 21.9 \\
\hline & Calcareous gyttja & 9.5 & 29.8 & 20.3 & 20.9 & 11.0 & 26.6 \\
\hline & Detritus gyttja & 26.8 & 93.1 & 66.3 & 52.7 & 30.4 & 75.5 \\
\hline & Dy & 2.8 & 4.1 & 1.3 & 3.4 & 2.9 & 3.8 \\
\hline \multirow[t]{4}{*}{$\mathrm{SO}_{4}^{2-}[\mathrm{mg} / \mathrm{L}]$} & Lacustrine chalk & 7.3 & 104.0 & 96.7 & 35.4 & 11.2 & 71.0 \\
\hline & Calcareous gyttja & 40.5 & 344.2 & 303.8 & 162.2 & 67.1 & 262.4 \\
\hline & Detritus gyttja & 357.8 & 947.2 & 589.4 & 737.0 & 533.2 & 934.0 \\
\hline & Dy & 6.00 & 10.8 & 4.9 & 7.8 & 6.4 & 9.4 \\
\hline \multirow[t]{4}{*}{$\mathrm{HCO}_{3}^{-}[\mathrm{mg} / \mathrm{L}]$} & Lacustrine chalk & 278.0 & 436.2 & 158.2 & 322.4 & 281.4 & 353.9 \\
\hline & Calcareous gyttja & 233.0 & 419.0 & 186.0 & 299.8 & 261.9 & 358.6 \\
\hline & Detritus gyttja & 263.0 & 346.0 & 83.0 & 308.3 & 280.0 & 336.4 \\
\hline & Dy & 12.5 & 22.5 & 10.0 & 19.2 & 16.1 & 22.0 \\
\hline \multirow[t]{4}{*}{$\mathrm{PO}_{4}^{3-}[\mathrm{mg} / \mathrm{L}]$} & Lacustrine chalk & 0.06 & 0.08 & 0.02 & 0.07 & 0.06 & 0.08 \\
\hline & Calcareous gyttja & 0.10 & 0.42 & 0.32 & 0.23 & 0.15 & 0.34 \\
\hline & Detritus gyttja & 0.35 & 0.57 & 0.22 & 0.47 & 0.39 & 0.54 \\
\hline & Dy & 0.21 & 1.33 & 1.12 & 0.61 & 0.21 & 1.01 \\
\hline
\end{tabular}

* Sampling points—see Table 1

compared to water from other sediments. It had a much lower $\mathrm{pH}$, which clearly results from the high content of organic matter, and there was a slight $\mathrm{pH}$ increase with the depth increasing (Fig. 4). It also had a different chemical composition; dominated ions are $\mathrm{SO}_{4}{ }^{2-}$ or $\mathrm{Ca}^{2+}$ and $\mathrm{SO}_{4-}$
$\mathrm{Ca}$ or $\mathrm{SO}_{4}-\mathrm{HCO}_{3}-\mathrm{Ca}$ type of water. The highest concentration of $\mathrm{Zn}^{2+}, \mathrm{Co}^{2+}, \mathrm{Cd}^{2+}$ (Table 6) and a relatively higher mineralization (Table 5) were discovered in them. In the depth range of $15-30 \mathrm{~cm}$, much higher values of mineralization $(2032 \mathrm{mg} / \mathrm{L})$ were found, and in the depth 
Table 6 Hydrogeochemical background values of selected heavy metals in interstitial water

\begin{tabular}{|c|c|c|c|c|c|c|c|}
\hline Parameter & Type of sediment* & Min & $\operatorname{Max}$ & Interval & Mean value & Percentile $16 \%$ & Percentile $84 \%$ \\
\hline \multirow[t]{4}{*}{$\mathrm{Fe}^{2+}[\mathrm{mg} / \mathrm{L}]$} & Lacustrine chalk & 0.011 & 0.070 & 0.059 & 0.043 & 0.014 & 0.070 \\
\hline & Calcareous gyttja & 0.026 & 0.860 & 0.834 & 0.156 & 0.033 & 0.193 \\
\hline & Detritus gyttja & 0.032 & 0.046 & 0.014 & 0.039 & 0.034 & 0.044 \\
\hline & Dy & 0.072 & 0.290 & 0.218 & 0.150 & 0.081 & 0.220 \\
\hline \multirow[t]{4}{*}{$\mathrm{Mn}^{2+}[\mathrm{mg} / \mathrm{L}]$} & Lacustrine chalk & 0.003 & 0.036 & 0.033 & 0.017 & 0.004 & 0.033 \\
\hline & Calcareous gyttja & 0.013 & 0.462 & 0.449 & 0.162 & 0.020 & 0.355 \\
\hline & Detritus gyttja & 0.124 & 0.242 & 0.118 & 0.173 & 0.133 & 0.213 \\
\hline & Dy & 0.023 & 0.061 & 0.038 & 0.036 & 0.025 & 0.048 \\
\hline \multirow[t]{4}{*}{$\mathrm{Zn}^{2+}[\mathrm{mg} / \mathrm{L}]$} & Lacustrine chalk & 0.002 & 0.021 & 0.019 & 0.013 & 0.004 & 0.017 \\
\hline & Calcareous gyttja & 0.018 & 0.053 & 0.035 & 0.040 & 0.029 & 0.052 \\
\hline & Detritus gyttja & 0.097 & 0.147 & 0.050 & 0.124 & 0.107 & 0.141 \\
\hline & Dy & 0.040 & 0.120 & 0.080 & 0.075 & 0.043 & 0.108 \\
\hline \multirow[t]{4}{*}{$\mathrm{Co}^{2+}[\mathrm{mg} / \mathrm{L}]$} & Lacustrine chalk & 0.0002 & 0.0007 & 0.0005 & 0.0003 & 0.0002 & 0.0005 \\
\hline & Calcareous gyttja & 0.0002 & 0.0005 & 0.0003 & 0.0004 & 0.0003 & 0.0005 \\
\hline & Detritus gyttja & 0.0006 & 0.0009 & 0.0003 & 0.0008 & 0.0007 & 0.0009 \\
\hline & Dy & 0.0002 & 0.0002 & 0.0000 & 0.0002 & 0.0002 & 0.0002 \\
\hline \multirow[t]{4}{*}{$\mathrm{Pb}^{2+}[\mathrm{mg} / \mathrm{L}]$} & Lacustrine chalk & $<0.0001$ & 0.0022 & - & 0.0008 & - & - \\
\hline & Calcareous gyttja & 0.0001 & 0.0105 & 0.0103 & 0.0026 & 0.0002 & 0.0068 \\
\hline & Detritus gyttja & 0.0001 & 0.0002 & 0.0001 & 0.0001 & 0.0001 & 0.0002 \\
\hline & Dy & 0.0092 & 0.0276 & 0.0184 & 0.0174 & 0.0118 & 0.0231 \\
\hline \multirow[t]{4}{*}{$\mathrm{Cd}^{2+}[\mathrm{mg} / \mathrm{L}]$} & Lacustrine chalk & $<0.0003$ & 0.0005 & - & 0.0002 & - & - \\
\hline & Calcareous gyttja & $<0.0003$ & 0.0008 & - & 0.0003 & - & - \\
\hline & Detritus gyttja & 0.0006 & 0.0007 & 0.0001 & 0.0007 & 0.0006 & 0.0007 \\
\hline & Dy & $<0.0003$ & $<0.0003$ & - & $<0.0003$ & - & - \\
\hline \multirow[t]{4}{*}{$\mathrm{Cr}^{3+}[\mathrm{mg} / \mathrm{L}]$} & Lacustrine chalk & $<0.005$ & $<0.005$ & - & $<0.005$ & - & - \\
\hline & Calcareous gyttja & $<0.005$ & 0.040 & - & 0.0078 & - & - \\
\hline & Detritus gyttja & $<0.005$ & 0.0071 & - & 0.0045 & - & - \\
\hline & Dy & $<0.005$ & $<0.005$ & - & $<0.005$ & - & - \\
\hline
\end{tabular}

* Sampling points—see Table 1

range of $30-45 \mathrm{~cm}$ higher concentration of nitrates $(103 \mathrm{mg} / \mathrm{L})$ were discovered. Such situation is caused by sewage treatment plant, localized near the Czarna Hańcza River, which inflow to Lake Wigry close to W-5 point. This is specific for environment impacted by human land use, first of all industrial wastewater, domestic sewage discharge and runoff from agricultural soil (e.g. Kerfoot et al. 1994; Keller et al. 2007).

This water, particularly in the upper part of the sediment, may have a tendency towards seasonal variation. Their enrichment in phosphorus and nitrogen depends on the deposit in Hańczańska Bay brought by the Czarna Hańcza River (Zdanowski and Hutorowicz 1997). The study of the chemical composition of water from this river (Migaszewski et al. 2003) showed an oversize in the ammonium and nitrate content, presumably associated with a close proximity to rural households and tributary water from sewage treatment plants in nearest located town Suwałki. This influences the fact that eutrophication processes are the greatest threat to the quality of water and sediment in Lake Wigry. Chemical composition of both surface water and interstitial water is greatly influenced by the organic matter content in the sediment (Thresh et al. 1944). Sulphate is generally present in low concentrations in lakes. However, within eutrophic lakes where organic matter availability is higher, sulphate concentrations increase (Holmer and Storkholm 2001). General decrease of $\mathrm{SO}_{4}{ }^{2-}$ ion concentration in interstitial solution with sediment depth can be explained by sulphate reduction. Furthermore, during remineralization of organic matter, microbes in the sediment take up (Carman and Rahm 1997).

Interstitial water samples from isolated dystrophic lake (W-3; Table 5, Fig. 5) had definitely different chemical 
compositions. Their mineralization was very low (49-69 mg/L), and $\mathrm{pH}$ changed from 7.25 to 8.01. Chemical composition was dominated by ions: $\mathrm{HCO}_{3}{ }^{-}, \mathrm{SO}_{4}{ }^{2-}$, $\mathrm{Ca}^{2+}$ and $\mathrm{Na}^{+}$, but their hydrogeochemical type changed with depth, from the $\mathrm{HCO}_{3}-\mathrm{Ca}-\mathrm{SO}_{4}$, via $\mathrm{HCO}_{3}-\mathrm{SO}_{4}-\mathrm{Ca}-$ $\mathrm{Na}-\mathrm{HCO}_{3}$ and $\mathrm{SO}_{4}-\mathrm{K}-\mathrm{Ca}$, to the $\mathrm{HCO}_{3}-\mathrm{SO}_{4}-\mathrm{Na}-\mathrm{Ca}$.

In interstitial water from sediment of dystrophic lake, high concentrations of $\mathrm{Fe}^{2+}(0.15 \mathrm{mg} / \mathrm{L})$ and the highest mean concentrations of $\mathrm{Pb}^{2+}(0.0174 \mathrm{mg} / \mathrm{L})$ occurred (Table 6). Although overlying water was acidic and had very low mineralization, it was determined that interstitial water $\mathrm{pH}$ increased and water composition strongly changed with the depth. This can be due to lithological variability of sediment, and decrease content of organic matter with depth and increase content of calcium carbonate.

Variation of selected metal concentrations in water samples in the individual sediment segment within the vertical profile and overlying water is shown on Fig. 6. The forms of iron and manganese are considered to play a major role in the availability of nutrients and trace metals in interstitial water. Under aerobic conditions, they are found as $\mathrm{Fe}^{3+}$ and $\mathrm{Mn}^{4+}$, respectively, and as insoluble oxide/hydroxides, which have very large surface areas. Many trace elements and oxy-anions can be adsorbed in such surfaces. When oxides undergo reduction (to $\mathrm{Fe}^{2+}$ and $\mathrm{Mn}^{2+}$ ), a large portion of trace elements undergo dissolution to be released into the pore water (Santschi 1990). Gu et al. (1996) showed that natural organic matter plays a role in stabilizing iron oxide colloids. Lovley et al. (1996) showed that humic acids can indirectly affect the distribution of iron in sediments by stimulating microbial reduction of $\mathrm{Fe}^{3+}$. In our studies, the highest concentration of $\mathrm{Fe}^{2+}$ ions occurred in overlying water in W-5 (Hańczańska Bay) and in W-3 (dystrophic lake) positions. Also in these locations, the highest organic matter content was stated. The concentration of iron in the interstitial water generally decreased with depth. An exception was found in water collected from the sediment in W-1 position, where the metal concentration increased with depth. In turn, the concentration of $\mathrm{Mn}^{2+}$ ions decreased with depth or to a certain depth increased and then further decreased (Fig. 6). For the ions of other metals, it was generally observed that concentrations decreased with the depth of sampling. The relatively higher concentrations were noted for samples collected from a depth of $40-50 \mathrm{~cm}$. The exceptions were samples from dystrophic lake, in which the concentration variability in function of depth is characterized by distinct irregularity.

In the region of Lake Wigry, some interstitial water analyses separated from the sands were investigated by Stangenberg (1934) and Rutkowski et al. (2006). The high permeability rate of such deposits and the easy exchange of

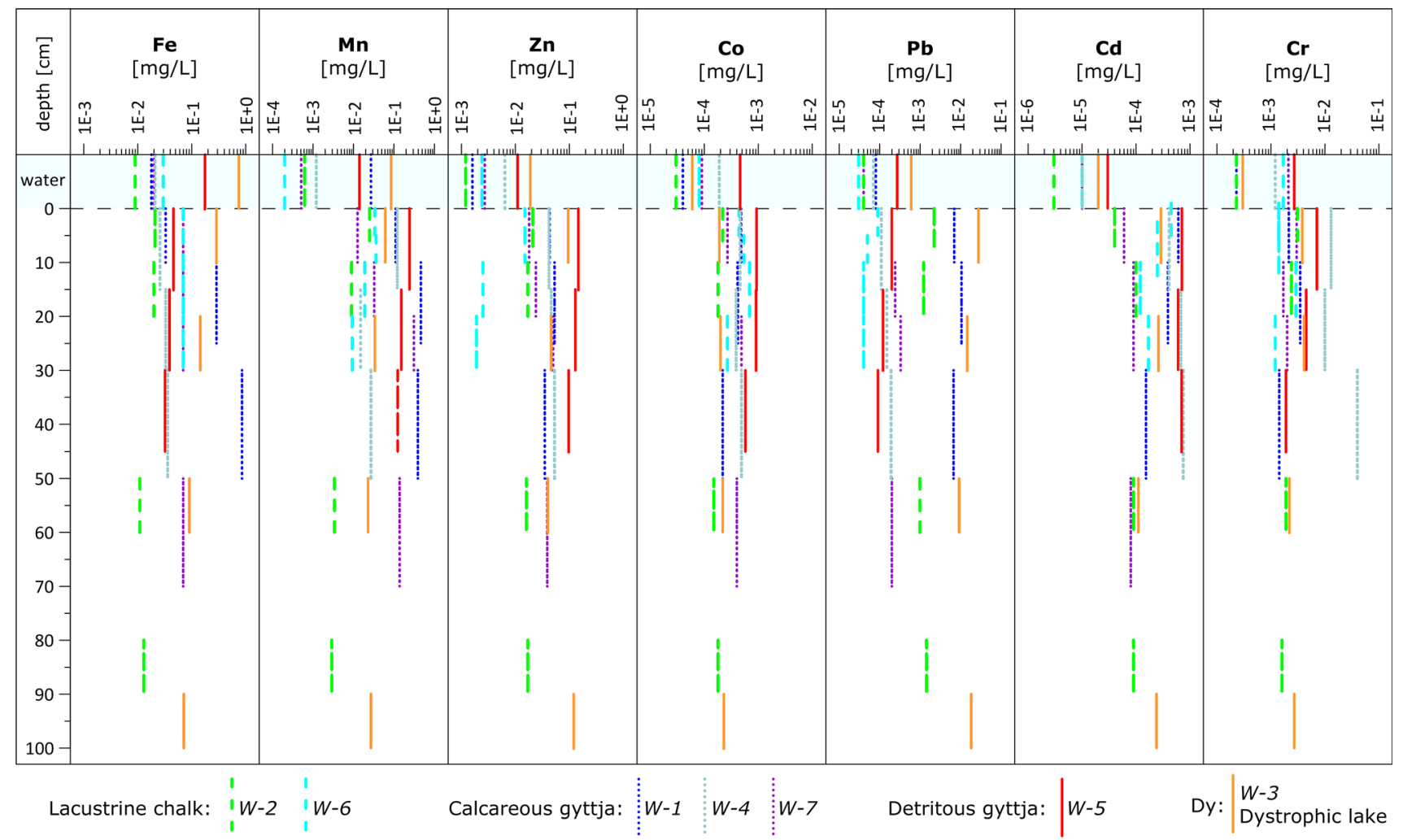

Fig. 6 Variation of selected metal concentration in overlaying water and interstitial water in the vertical profile of sediments from Lake Wigry 
water suggest that this is almost the same chemical composition of interstitial and overlying water.

It should be also taken into account the fact that first of all in the littoral zone the changes in the distribution of trace metals between the solid particles and interstitial water, and at the border of water and sediments may be also affected by bioturbation (Vale and Sundby 1998; Ciutat et al. 2005).

\section{Conclusions}

Studies of interstitial solutions collected from different zones and lithological type of sediments showed marked chemical composition differences between the carbonate and organic sediments. The highest mineralization $(2032 \mathrm{mg} / \mathrm{L})$ was generally found in the interstitial water obtained from the detritus gyttja localized in the shallow positions, which are more exposed to pollution. The highest trace metals and nutrients content in the sediments and interstitial water found in the Czarna Hańcza River estuary were a result of the input from increasing industrial wastewater, domestic sewage discharge and runoff from agricultural soil.

A greater resistance to adsorption of contaminants characterizes sediments composed of the lacustrine chalk; mineralization of their pore solutions was significantly lower. This fact is probably also affected by very low mineralization and chemical composition of overlying water and sediment.

Acknowledgments These studies were carried out within the project of the Faculty of Geology, Geophysics and Environment Protection at the AGH University of Science and Technology in Kraków (11.11.140.199 and 11.11.140.797). The study was possible thanks to the kindness of Professor J. Rutkowski and the staff of the Wigierski National Park.

Open Access This article is distributed under the terms of the Creative Commons Attribution 4.0 International License (http://crea tivecommons.org/licenses/by/4.0/), which permits unrestricted use, distribution, and reproduction in any medium, provided you give appropriate credit to the original author(s) and the source, provide a link to the Creative Commons license, and indicate if changes were made.

\section{References}

Adams WJ, Burgess RM, Gold-Bouchot G, Leblanc L, Liber K, Williamson B (2000) Porewater chemistry: effects of sampling, storage, handling and toxicity testing. In: Carr RS, Nipper M (eds) Porewater Toxicity Testing: Biological Chemical and Ecological Considerations. SETAC Press, Pensacola, pp 95-124

Aggett J, O'Brien GA (1985) Detailed model for the mobility of arsenic in lacustrine sediments based on measurements in Lake Ohakuri. Environ Sci and Technol 19:231-238
Alekin OA (1970) Osnovy hydrokhimii (Principles of hydrochemistry). Hydrometeorologicheskoe Iztlat, Leningrad

Aleksander-Kwaterczak U, Kostka A (2011) Lead in the environment of Lake Wigry (NE Poland). Limnol Rev 11(2):59-68

Aleksander-Kwaterczak U, Prosowicz D (2007) Distribution of Cd, and $\mathrm{Pb}$ in the lake sediments cores from the Hanczanska Bay (Wigry Lake, NE Poland). Limnol Rev 7(4):219-223

Aleksander-Kwaterczak U, Prosowicz D, Rutkowski J, Szczepańska J (2009) Changes of selected micro-pollution concentrations in the long carbonate sediment cores of the southern part of Wigry Lake (NE Poland). Pol J Environ Stud 18(2B):51-55

Antweiler RC, Taylor HE (2008) Evaluation of statistical treatments of left-censored environmental data using coincident uncensored data sets: I. summary statistics. Environ Sci Technol 42:3732-3738

Bajkiewicz-Grabowska E (2009) Water circulation in a lake at extreme water levels: lake Wigry case study. Limnol Rev $9(2-3): 63-72$

Ber A (2009) The Wigry Lake surroundings geology, geomorphology and origin against tectonic structures of the deep basement. In: Rutkowski J, Krzysztofiak L (eds) History of the lake in the light of geological and paleoecological studies, Lake Wigry. Stow. "Człowiek i Przyroda", Suwałki, pp. 13-30 (in Polish)

Berner RA (1980) Early Diagenesis: A theoretical approach. Princeton University Press, Princeton

Brannon JM, Plumb RH Jr, Smith I Jr (1980) Long-term release of heavy metals from sediments. In: Baker RA (eds) Contaminants and Sediments, Ann Arbor Sci. pp. 221-266

Carman R, Rahm L (1997) Early diagenesis and chemical characteristics of interstitial water and sediments in the deep deposition bottoms of the Baltic proper. J Sea Res 37:25-47

Ciutat A, Gerino M, Mesmer-Dudons N, Anschutz P, Boudou A (2005) Cadmium bioaccumulation in Tubificidae from the overlying water source and effects on bioturbation. Ecotoxicol and Environ Saf 60:237-246

Commission Directive 2009/90/EC of 31 July 2009 laying down, pursuant to Directive 2000/60/EC of the European Parliament and of the Council, technical specifications for chemical analysis and monitoring of water status

Cudowski A (2015) Dissolved reactive manganese as a new index determining the trophic status of limnic waters. Ecol Indic 48:721-727

Dowgiałło J, Kleczkowski AS, Macioszczyk T, Różkowski A (2002) Hydrogeol Dict. PIG, Warszawa (in Polish)

Drzymulska D, Fiłoc M, Kupryjanowicz M (2014) Reconstruction of landscape paleohydrology using the sediment archives of three dystrophic lakes in northeastern Poland. J Paleolimnol 51(1):45-62

Elder JF (1989) Metal biogeochemistry in surface-water systems-A review of principles and concepts: U.S. Geological Survey Circular 1013

Górniak A (2004) Dystrophy advance in suchar type lakes of Wigry National Park. Rocz Augustowsko-Suw 4:45-52 (in Polish)

Gu B, Mehlhorn TL, Liang L, McCarthy JF (1996) Competitive adsorption, displacement, and transport of organic matter on iron oxide: iI. displacement and transport. Geochim Cosmochim Acta 60:2977-2992

Holmer M, Storkholm P (2001) Sulfate reduction and sulfur cycling in lake sediments: a review. Freshw Biol 46:431-451

Huggett RJ (2007) Fundamentals of geomorphology, 2nd edn. Routledge Fundamentals of Physical Geography, London

Jańczak J (1999) The Atlas of Polish Lakes. Tom III, IMGiW, Poznań (in Polish)

Kamiński M (1999) Lake Wigry-the lake "adopted" by the International Association of Theoretical and Applied Limnology (SIL) "Lake Adoption" Project. Pol J Ecol 57(2):215-224 
Keller W, Yan ND, Gunn JM, Heneberry J (2007) Recovery of acidified lakes: lessons from Sudbury, Ontario, Canada. In: Brimblecombe P, Hara H, Houle D, Novak M (eds) Acid RainDeposition to Recovery, pp. 317-322

Kerfoot WC, Lauster G, Robbins JA (1994) Paleolimnological study of copper mining around Lake Superior: artificial varves from Portage Lake provide and high resolution record. Limnol Oceanogr 39(3):649-669

Kļavinš M, Briede A, Kļavina I, Rodinov V (1995) Metals in sediments of lakes in Latvia. Environ Int 21(4):451-458

Kondracki J (1988) Physical Geography of Poland. PWN, Warszawa (in Polish)

Lovley DR, Coates JD, Blunt-Harris EL, Phillips EJP, Woodward JC (1996) Humic substances as electron receptors for microbial respiration. Nature 382:445-448

Maassen S, Uhlmann D, Röske I (2005) Sediment and pore water composition as a basis for the trophic evaluation of standing waters. Hydrobiologia 543:55-70

Migaszewski ZM, Gałuszka A, Pasławski P (2003) Baseline versus background concentrations of trace elements in sediments of Lake Wigry, NE Poland. Limnol Rev 3:65-172

Myślińska E (1974) Pore water in cohesive soils. Biuletyn Geologiczny, Wydawnictwo Uniwersytetu Warszawskiego 17:73-167 (in Polish)

Paprocka A, Leśniak PM (2008) $\mathrm{CO}_{2}$ flux from Lake Wigry (NEPoland). In: Bajkiewicz-Grabowska E, Borowiak D (eds) Anthropogenic and natural transformations of lakes, vol 2., Department of LimnologyUniversity of Gdańsk, Polish Limnological Society, pp 143-145

PN-C-04540-01 (1990) Woda i ścieki. Badania pH, kwasowości i zasadowości. Oznaczanie pH wód i ścieków o przewodności elektrolitycznej właściwej $10 \mathrm{mikrosimensów/cm} \mathrm{i} \mathrm{powyżej}$ metodą elektrometryczną (in Polish)

PN-EN ISO 17294-1 (2007) Jakość wody. Zastosowanie spektrometrii mas z plazmą wzbudzoną indukcyjnie (ICP-MS). Część 1: Wytyczne ogólne (in Polish)

PN-EN ISO 17294-2 (2006) Jakość wody. Zastosowanie spektrometrii mas z plazmą wzbudzoną indukcyjnie (ICP-MS). Część 2: Oznaczanie 62 pierwiastków (in Polish)

PN-EN ISO 9297 (1994) Jakość wody. Oznaczanie chlorków. Metoda miareczkowania azotanem srebra w obecności chromianu jako wskaźnika (Metoda Mohra) (in Polish)

PN-EN ISO 9963-1 (2001 + Ap1:2004) Jakość wody. Oznaczanie zasadowości. Część 1: Oznaczanie zasadowości ogólnej i zasadowości wobec fenoloftaleiny (in Polish)

Prosowicz D, Aleksander-Kwaterczak U, Kostka A (2009) Trace metals in the sediments of Wigry Lake. In: Rutkowski J, Krzysztofiak L (eds) History of the lake in the light of geological and paleoecological studies, Lake Wigry. Stow. "Człowiek i Przyroda", Suwałki, pp. 110-130 (in Polish)

Rutkowski J, Król K, Krzysztofiak L, Prosowicz D (2002) Recent sediment of Lake Wigry (Bryzgiel Basin). Limnol Rev 2:353-362

Rutkowski J, Król K, Krzysztofiak L, Prosowicz D (2003) Recent sediment of Lake Wigry (Szyja Basin), NE Poland. Limnol Rev 3:197-203

Rutkowski J, Szczepańska J, Król K, Krzysztofiak L (2006) The chemical composition of pore water in the lacustrine deposits of Wigry National Park. Prace Komisji Paleogeografii Czwartorzędu PAU, Kraków IV: 87-95 (in Polish)
Rutkowski J, Król K, Szczepańska J (2007) Lithology of the profundal sediments in Słupiańska Bay (Wigry Lake, NE Poland)—introduction to interdisciplinary study. Geochronometria 27:47-52

Rutkowski J, Prosowicz D, Aleksander-Kwaterczak U, Krzysztofiak L (2009) Sediment of Lake Wigry. In: Rutkowski J, Krzysztofiak L (eds) History of the lake in the light of geological and paleoecological studies, Lake Wigry. Stow. "Człowiek i Przyroda", Suwałki, pp. 83-109 (in Polish)

Salomons W (1995) Environmental impact of metals derived from mining activities: processes, predictions, prevention. J Geochem Explor 52:5-23

Salomons W, Förstner U (1984) Metals in the hydrocycle. Springer, Berlin

Salomons W, de Rooij NM, Kerdijk H, Bril J (1987) Sediments as a source of contaminants. Hydrobiologia 149:13-30

Santschi P (1990) Chemical processes at the sediment-water interface. Mar Chem 30:269-315

Schulz HD (2006) Quantification of early diagenesis: Dissolved constituents in marine pore water. In: Schulz HD, Zabel M (eds) Marine Geochemistry. Springer, Berlin, pp 73-124

Song Y, Müller G (1995) Biogeochemical cycling of nutrients and trace metals in anoxic freshwater sediments of the Nackar River, Germany. Mar Freshw Res 46:237-243

Stangenberg M (1934) Psammolitoral, ein extrem eutrophes Wassermedium. Arch Hydrobiol i Ryb 8:273-284

Stangenberg M (1938) Chemical composition of bottom sediments of Suwałki Region lakes. Rozpr Inst Bad Lasów Państw 31A:5-40 (in Polish)

Suedel BC, Rodgers JH, Clifford PA (1993) Bioavailability of fluoranthene in freshwater sediment toxicity tests. Environ Toxicol Chem 12:155-165

Szczepańska J, Kmiecik E (2005) Estimation of groundwater chemical state on the base of monitoring investigation. Uczelniane Wydawnictwa Naukowo-Dydaktyczne AGH, Kraków (in Polish)

Szczepańska J, Szczepański A, Ngoc-Ky Vu (1980) On the influence of pressures on results of studies on pore water chemistry. Geol Q 24(4):905-919 (in Polish)

Thresh JC, Suckling EV, Beale JF (1944) The examination of water supplies. London

Vale C, Sundby B (1998) The interactions between living organisms and metals in intertidal and subtidal sediments. In: Langston WJ, Bebiano MJ (eds) Metal metabolism in aquatic environments. Chapman and Hall, London, Ch. 2, pp. 19-29

Wällstedt T, Borg H (2003) Effects of experimental acidification on mobilisation of metals from sediments of limed and non-limed lakes. Environ Pollut 126:381-391

Williamson B, Burgess RM (2000) Sediment and porewater chemistry. In: Carr RS, Nipper M (eds) Porewater Toxicity Testing: Biological Chemical and Ecological Considerations. SETAC Press, Pensacola

Woroniecka-Stasiak A (1980) Chemical composition of interstitial waters in bottom sediments of some Polish lakes of the Wigry group (Northern Poland). Acta Hydrobiol 22:347-360

Zdanowski B, Hutorowicz A (1997) Hydrochemical characteristics of Czarna Hańcza River and their influence on Hańcza and Wigry Lakes. In: Krzysztofiak L (ed) Integrated Natural Environment Monitoring. Wigry Base station, Warszawa, pp 29-47 (in Polish) 